\title{
Evaluation of the Adequacy and Utilization of Contingency Fund in Building Projects in Nigeria
}

\author{
0. F. Akinradewo*, 0. A. Awodele \\ Department of Quantity Surveying, Federal University of Technology, Akure, Nigeria \\ Email: ^fakol30@yahoo.com
}

How to cite this paper: Akinradewo, O.F. and O. A. Awodele, O.A. (2016) Evaluation of the Adequacy and Utilization of Contingency Fund in Building Projects in Nigeria. Open Access Library Journal, 3: e2925.

http://dx.doi.org/10.4236/oalib.1102925

Received: August 25, 2016

Accepted: September 25, 2016

Published: September 28, 2016

Copyright @ 2016 by authors and Open Access Library Inc.

This work is licensed under the Creative Commons Attribution International License (CC BY 4.0).

http://creativecommons.org/licenses/by/4.0/

\begin{abstract}
Contingency fund is allowed in the cost estimate to cater for risks which always lead to additional cost. The study used archival data to assess the accuracy of contingency sum and utilization among various types of claims. Data collected were analysed using percentile and Pearson's coefficient of correlation. The study reveals that the current allowance as contingency is $5 \%$ of the base line estimates while additional cost is $18 \%$ which implies a shortfall of $13 \%$. Furthermore, the study shows that the relationship among contingencies, base line estimates and final cost is statistically significant at 0.01 . The study concludes that using percentage in allocating contingency based on subjective approach or at the discretion of the consultants is grossly inadequate. The study recommends that allocation of contingency sum should be based on cost analysis of similar completed projects and that a realistic contingency sum should be about $20 \%$ of the base line estimate.
\end{abstract}

\section{Subject Areas}

Environmental Sciences

\section{Keywords}

Additional Cost, Base Line Estimate, Contingency Fund, Final Cost and Nigeria

\section{Introduction}

Execution phase of construction projects involves various human activities and manipulation of series of resources in achieving the finish product. In this complex situation, an accurate cost estimate cannot be achieved at planning phase of the project. Therefore, there is a need for contingency fund to cater for unforeseen conditions or deviations that may occur during the construction phase of the project. [1] observed that there was no standard definition for contingency. However, contingency has been 
defined in various ways by several authors. [2] described contingency as funds included in project budgets to manage risk and achieve project goals. [3] defined contingency as the amount of money needed above the estimate to reduce the risk overruns of project objectives to a level acceptable to the organisation. [4] described contingency as an amount the contractor was instructed to add to his tender in order to absorb or cushion unforeseen extras. [5] observed that contingency fund was not intent to cover changes in scope or schedule, profit, overhead, acts of God, force majeure situations and earthquakes.

According to [5], any serious changes to construction project budget that is not catered for by contingency fund may hamper the progress of work or even lead to abandonment of the project which the client never wishes. The study concludes that an assurance of reliable and effective construction contingency is essential to client's satisfaction on the final cost. [6] observed that accuracy of cost estimation was measured by the magnitude of deviation between estimated cost of a project and its final cost. The study also concluded that the relative percentage variance between estimated project cost and actual project cost was expected to be less when contingency fund was included in the base line estimate than when it was not.

Several research studies have been carried out in the area of contingency fund in $\mathrm{Ni}$ geria. Notable among them were [6], which worked on appraisal of the performance of contingency cost provision for building projects in Nigeria; [7] which studied the effectiveness of construction contingency-a statistical analysis and [8], which researched on effectiveness of contingency sum as risk tool for construction projects in Niger Delta, Nigeria. Some of these studies were based on questionnaire survey while the geographical location of some of the previous studies was different from the current area of study. This prompts a further study of contingency fund.

As a result of this, the study focuses on the evaluation of the adequacy of allowed construction contingency fund in building projects. It went further to evaluate the utilization of contingency fund among various types of claims. The study also reviewed the challenges associated with the management of contingency fund. In line with the specific objectives of the study as stated above, two null hypotheses were postulated, which would help to determine the statistical relationship among the allowed contingency fund, the base line cost estimate and final contract cost. These null hypotheses are as follows:

$\mathrm{H}_{\mathrm{o}} 1$ : There is no significant relationship between contingency fund and base line estimate.

$\mathrm{H}_{\mathrm{o}} 2$ : There is no significant relationship between contingency fund and final contract sum.

\section{Challenges Associated with the Management of Contingency Fund in Building Projects}

Several studies such as [5] [9]-[12] have confirmed that contingency is not managed or reported by project and cost managers. This is due to the challenges associated with the 
management of contingency fund. [12] and [13] submitted that the problem of incorporating project complexity into actual management is affecting the construction contingency management. [2] also confirmed that project complexity and inherent uncertainty of the financial performance of constructed facilities, development funding, control of cost and schedules make exact budget needs impossible to forecast accurately. According to [2], contingency fund management are not organised by clearly defined procedures compared to other managerial duties, such as estimating and scheduling. [14] stressed the important of skills possessed by the proposed project manager in order to handle contingency fund and the entire project effectively. These skills required in managing contingency include communication, leadership, motivation, problem solving and negotiation. "Majority of these skills are not possessed by those who are managing contingency [14]". Another challenge is misuse of contingency fund by project managers. Contingency fund is not intended to cover such as changes in schedule, force majeure, profit and overhead. "However, in most cases contingency fund are used for these additional works" [10] [15]-[20].

[16] confirmed that many cost practitioners and project managers do not formally manage construction contingency fund. [5] asserted that most contingency fund is exhausted before completion of the project requiring additional fund. This has accounted for cost overrun in construction projects in Nigeria. Another important challenge of contingency is the way the fund is allocated in construction projects. [5] [16] [17] [21]-[23] submitted that contingency sum is usually expressed as a percentage mark-up on the base cost estimate. In Nigerian context, this percentage is usually based on subjective or intuition approach. "This has resulted in the inadequacy of the contingency fund as confirmed by previous studies such as [6] [7]". [8] also argued that contingency allowed for projects in Niger Delta area of Nigeria are based on the discretions of the consultants and contractors, not a function of the estimated contract value and it is inadequate. Therefore, the challenges highlighted above needs to be addressed before a robust and adequate contingency fund can be achieved and managed for successful projects delivery within budgets.

\section{Research Methodology}

Archival data for the study was collected from 53 projects that had been completed with their attendant construction claims in Ondo State, Nigeria. Ondo State was established in 1976, its land area is about 15, 500 square kilometres and with population of about 3.5 million people according to 2006 census. Ondo State is an oil producing State in Nigeria with a gross domestic product (GDP) of about \$8.41. All the projects considered were constructed over a period of nine years (2006 to 2014). These comprise of 5 health services buildings; 34 institutional building projects; 2 residential buildings; 3 social services buildings; and 9 office buildings. The information collected on claims contained the activities of both main and subcontractors. "Thirty five percent" (35\%) of the projects had more than 4 floors, while the remaining "sixty five percent" (65\%) had less than 4 floors. 
The costs of the projects ranged from $\$ 24$ million to $\$ 4.1$ billion. The contracts were based on traditional system of project procurement. The assumptions made in the study includes that (i) the type of claims used as independent variables are linearly related to the initial contract sum/completion cost, (ii) change in projects characteristics and specifications do not materially affect the relationship between the types of claims and initial contract sums. The data collected were analysed with percentile and Pearson correlation using Excel and SPSS version 22 software. The base line cost estimate is the initial or original contract sum less the amount included therein as contingency fund. Percentile was used to compute average contingency and average claims while correlation was used to calculate the relationship between contingency fund and base line estimate/final contract sum.

\section{Results of Analysis}

Table 1 show that the average contingency allowed for the projects is about $5 \%$ while average claim is about $18 \%$. This implies that contingency is inadequate by $13 \%$. The table also indicate that all the projects had cost overruns.

Table 1. Base line estimate, contingency fund, final contract sum and amount of claims in completed building projects.

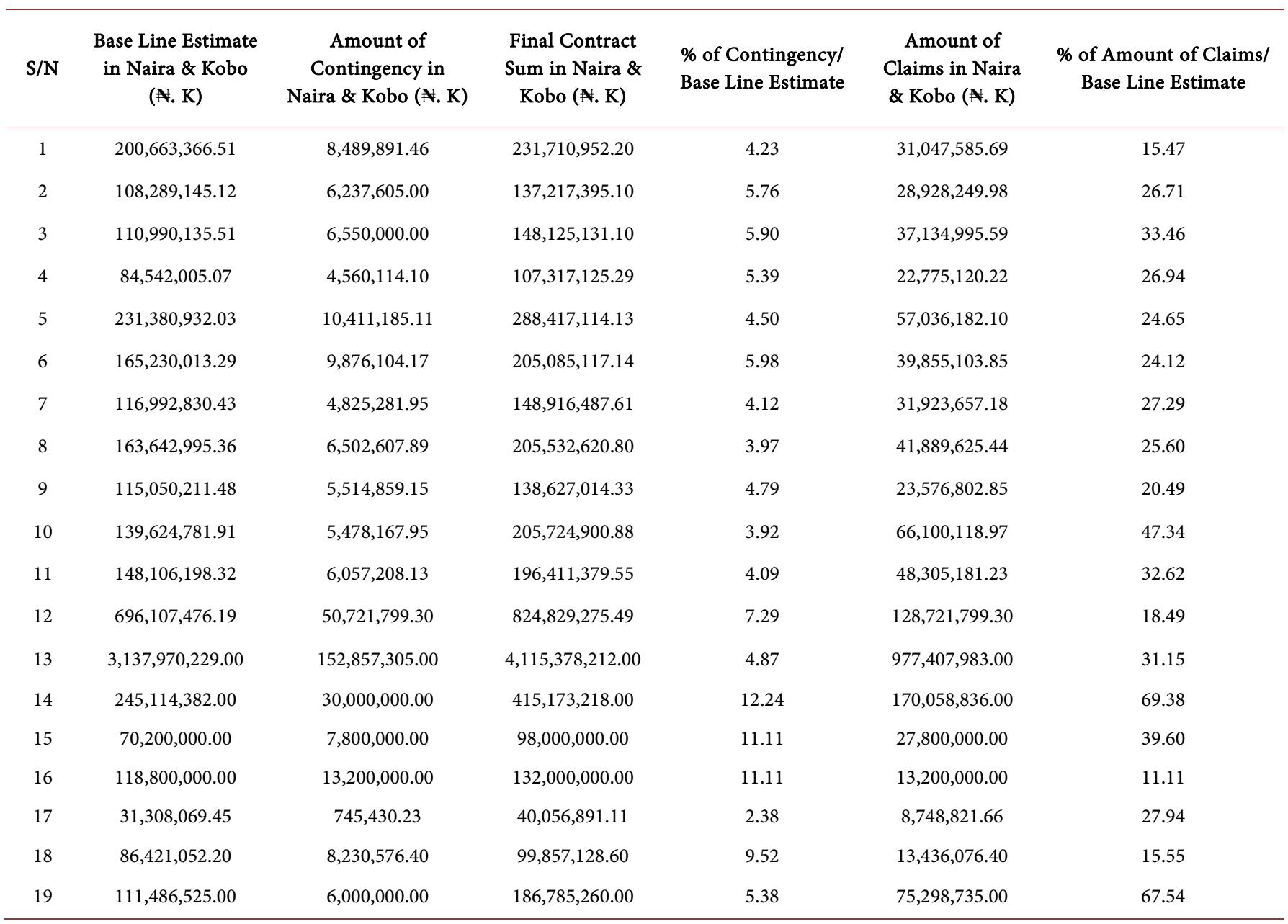




\section{Continued}

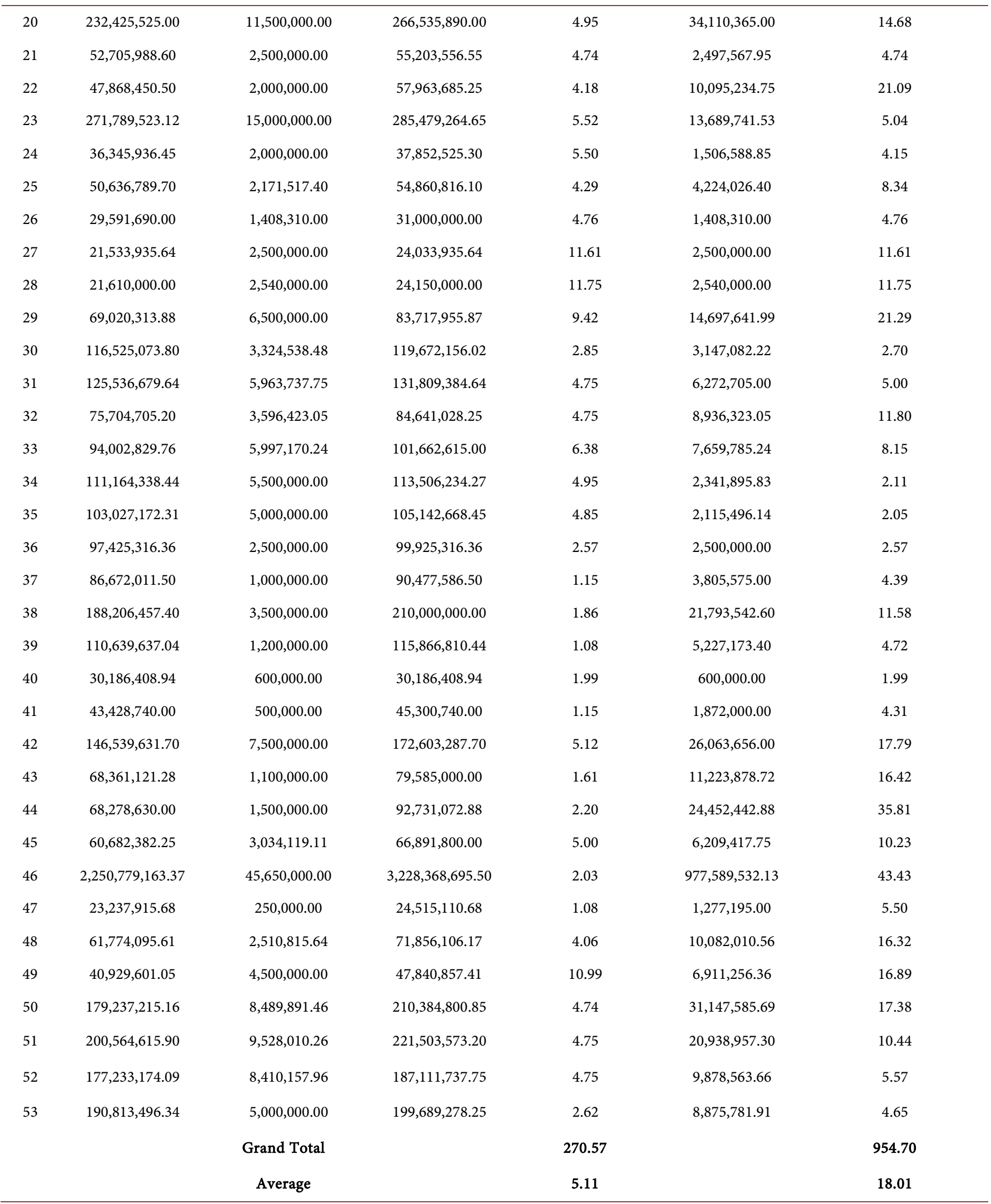


Table 2 indicates that the average amount expended from the contingency fund on contract ambiguity claims averaged (N31,433,379.46) about $54 \%$ which is the highest while the least amount was spent on acceleration claims (N2,396,195.03) which is about $4 \%$ and no amount was spent on delay claims. It is evident from (Table 2) that five out of the six types of claims headings used in this study should be given priority when decision is to be taken on the allocation of contingency fund on similar projects in the study area.

Table 3 presents the result correlation coefficient analysis carried out to establish the significance of the relationship between contingency fund and base line estimate/final

contract sum. Table 3 shows that the relationship between contingency fund and base line estimate/final contract sum were statistically significant at 0.01 level of significant. This implies that the null hypothesis which states that there is no significant relationship between contingency fund and base line estimate is rejected. This is equally true of the second hypothesis that states that there is no significant relationship between contingency fund and final contract sum. P values of 0.922 and 0.905 respectively signified a strong positive correlation.

\section{Discussion of Results}

The study reveals that contingency fund is inadequate by $13 \%$. This implies contingency fund cover only $28 \%$ of approved contract claims but did not cater for $72 \%$ of approved construction claims. This can be ascribed to uncontrollable inflation and foreign currency exchange rates in Nigeria. "A realistic contingency fund is about $20 \%$ from the analysis, this finding agrees with the $15 \%-20 \%$ contingency allowance previ-

Table 2. Distribution of the utilization of contingency fund among various types of claims.

\begin{tabular}{cccc}
\hline Types of Claims & $\begin{array}{c}\text { Average amount of claims in } \\
\text { naira \& kobo (\#. K) }\end{array}$ & $\begin{array}{c}\text { Percentage } \\
(\%)\end{array}$ & Rank \\
\hline Contract ambiguity claims & $31,433,379.46$ & 54.40 & 1 \\
Change claims & $13,839,799.76$ & 23.95 & 2 \\
Different site Conditions claims & $5,125,888.4$ & 8.87 & 3 \\
Extra works claims & $4,983,336.03$ & 8.63 & 4 \\
Acceleration claims & $2,396,195.28$ & 4.15 & 6 \\
Delay claims & $\underline{0.00}$ & $\underline{0.00}$ & 6 \\
Total & & 100.00 & \\
\hline
\end{tabular}

See Appendix 1 for the calculation of average amount of claims

Table 3. Relationship between contingency sum and base line estimate/final contract sum.

\begin{tabular}{cccc}
\hline & & Base line estimate & Final contract sum \\
\hline Contingency sum & Correlation value & $0.922^{* *}$ & $0.905^{* *}$ \\
Contingency sum & Sign (2-tailed) & 0.000 & 0.000 \\
\hline
\end{tabular}

${ }^{*}$ Correlation is significant at the 0.01 level (2-tailed) 
ously suggested by [24] and [25]". The result of this study also concurs with [8].

The result also indicates that contingency fund is used for five out of six types of claims adopted in the study. Contract ambiguity top the list in the usage of contingency fund, this may be due to inadequate time frame usually allowed by the clients for the preparation of contract documents. Interviews with the some consultants showed that in most cases, site investigations were not carry out prior to contract documentation. This may be the reason for ranking change claims as second among the six types of claims.

Finally, the result of the analysis shows that there is strong positive relationship between contingency fund and base line estimate/final project cost. This agreed with [26] that concluded realistic contingency fund must serve as the basis for decision making concerning financial viability of the variations and a base line for their control.

\section{Conclusions}

The following conclusions have been drawn from the results of the analysis.

1) The contingency sum allowed for building contracts is inadequate to cater for construction claims. This suggests that there is significant room for improvement in the method of allocating contingency through subjective or intuition approach in the study area.

2) The study reveals that contingency is used mostly for projects with contract ambiguity claims. This implies that these claim heads should be considered as part of the likely risks and uncertainties in allocating contingency fund.

3) The study shows that there is significant relationship between contingency fund and base line estimate/final contract cost. This implies that accurate prediction of contingency will be required to reduce cost overrun.

\section{Recommendations}

Based on the aforementioned findings, the following recommendations are made:

1) The calculation of contingency should be based on accurate cost analysis of similar completed projects with due consideration of design risks associated with the new contract so as to accommodate other factors that can lead to claims.

2) A realistic contingency should be $20 \%$ of the base line estimate in order to ensure that the building projects are executed within budget.

3) The provisions of the conditions of contract concerning the preparation final account should be amended to make it mandatory for the Quantity Surveyors to review and report contingency fund in building projects. This type of report will stand as lesson learnt from previous project which other can take a cue from in a similar situation.

\section{References}

[1] Moselhi, O. (1997) Risk Assessment and Contingency Estimating. AACE Transactions, Dallas, 13-16 July 1997, D\&RM/A 06. 
[2] Ford, D.N. (2002) Achieving Multiple Project Objectives through Contingency Management. Journal of Construction Engineering and Management, 128, 30-39.

http://dx.doi.org/10.1061/(ASCE)0733-9364(2002)128:1(30)

[3] PMI (2000) A Guide to the Project Management Body of Knowledge. Project Management Institute, Upper Darby.

[4] Kirkham, C.R. (2007) Ferry and Brandon's Cost Planning of Building. 8th Edition, Blackwell Publishing, Oxford.

[5] Bello, W.A. and Odusami, K.T. (2013) Weak Management of the Predictability of Contingency Allowance in Construction Projects in Nigeria. In: Smith, S.D. and Ahiaga Dagbui, D.D., Eds., Proceedings of 29th Annual ARCOM Conference, Association of Researchers in Construction Management, Reading, 2-4 September 2013, 969-978.

[6] Musa, M.M., Zubairu, I.K. and Bala, K. (2011) Appraisal of the Performance of Contingency Cost Provision for Building Projects in Nigeria. Journal of Environmental Technology, 4, 41-48.

[7] Bello, W.A and Odusami K.T. (2012) The Effectiveness of Construction Contingency in Contract Delivery in Nigeria. In: Kashiwagi, D., Ed., Proceedings of the Construction and Building Research Conference of the Royal Institution of Chartered Surveyors RICS COBRA 2012, Las Vegas, 10-13 September 2012, 1627-1636.

[8] Otali, M. and Odesola, I.A. (2014) Effectiveness Evaluation of Contingency Sum as a Risk Management Tool for Construction Projects in Niger Delta Nigeria. Ethiopian Journal of Environmental Studies \& Management, 7, 588-598. http://dx.doi.org/10.4314/ejesm.v7i6.1

[9] Rowe, J.F. (2006) A Construction Cost Contingency Tracking System (CTS). Cost Engineering, 48, 31-37.

[10] Baccarini, D. (2005) Understanding Project Cost Contingency: A Survey. Proceedings of the Queensland University of Technology Research Week, Brisbane, 4-8 July 2005, ID: 20855.

[11] Hogg, K. (2003) The Role of Quantity Surveying Profession in Accommodating Client Risk. Journal of Financial Management of Property and Construction, 8, 49-56.

[12] Sterman, J.D. (1994) Learning in about Complex Systems. System Dynamics Review, 10, 291-330. http://dx.doi.org/10.1002/sdr.4260100214

[13] Simon, H. (1995) The Sciences of the Artificial. MIT Press, Cambridge.

[14] Odusami, K.T. (2002) Perceptions of Construction Professionals Concerning Important Skills of Effective Project Leaders. Journal of Management in Engineering, 18, 61-67. http://dx.doi.org/10.1061/(ASCE)0742-597X(2002)18:2(61)

[15] Ahmad. I. (1992) Contingency Allocation: A Computer-Aided Approach. AACE transaction, Orlando, 28th June-1st July 1992, F. 5. 1-7.

[16] Touran, A. (1993) Probabilistic Cost Estimating with Subjective Correlations. Journal of Construction Engineering and Management, 119, 58-71. http://dx.doi.org/10.1061/(ASCE)0733-9364(1993)119:1(58)

[17] Baccarini, D. (2004) ACCURACY in Estimating Project Cost Construction Contingency-A Statistical Analysis. Proceedings of the Construction and Building Research Conference of RICS, Leeds, 7-8 September 2004, 7-8.

[18] Parsons Jr., E.L. (1999) Waste Management Project Contingency Analysis. US Department of Energy, Federal Energy Technology Centre. Morgantown, West Virginia. http://dx.doi.org/10.2172/10667

[19] Stevenson Jr., J.J. (1984) Determining Meaningful Estimate Contingency. Cost Engineering, 
26, 35-41.

[20] PMI (Project Management Institute) (2004) A Guide to the Project Management Body of Knowledge. 3rd Edition, PMI, Newtown Square.

[21] Picken, D.H. and Mak, S. (2001) Risk Analysis in Cost Planning and Its Effect on Efficiency in Capital Cost Budgeting. Logistics Information Management, 14, 318-329.

http://dx.doi.org/10.1108/EUM0000000006244

[22] Mak, S., Wong, J. and Picken, D. (1998) The Effect on Contingency Allowances of Using Risk Analysis in Capital Cost Estimating: A Hong Kong Case Study. Construction Management and Economics, 16, 615-619. http://dx.doi.org/10.1080/014461998371917

[23] Asamoah, O.R. (2008) Determining and Monitoring of Project Contingency Sum for Building Developments in Ghana. A Case Study in Ashanti and Greater Accra Regions. An Unpublished MSc Thesis Submitted to the Department of Building Technology, Faculty of Environmental and Developmental Studies.

[24] Aibinu, A.A. and Jagboro, G.O. (2002) The Effects of Construction Delays on Project Delivery in the Nigerian Construction Industry. International Journal of Project Management, 20, 593-599. http://dx.doi.org/10.1016/S0263-7863(02)00028-5

[25] Omoregie, A. and Radford, D. (2006) Infrastructure Delay and Cost Escalations Causes and Effects in Nigeria. De Montford University, School of Architecture, Leicester LE 19BH England.

[26] Akinsola, A.O. (1996) Neural Networks, Model for Predicting Building Projects' Contingency Allowance. Proceeding of Association of Reseachers in Construction Management (ARCOM Conference), Sheffield Hallam University, 11-13 September 1996, 507-516. 


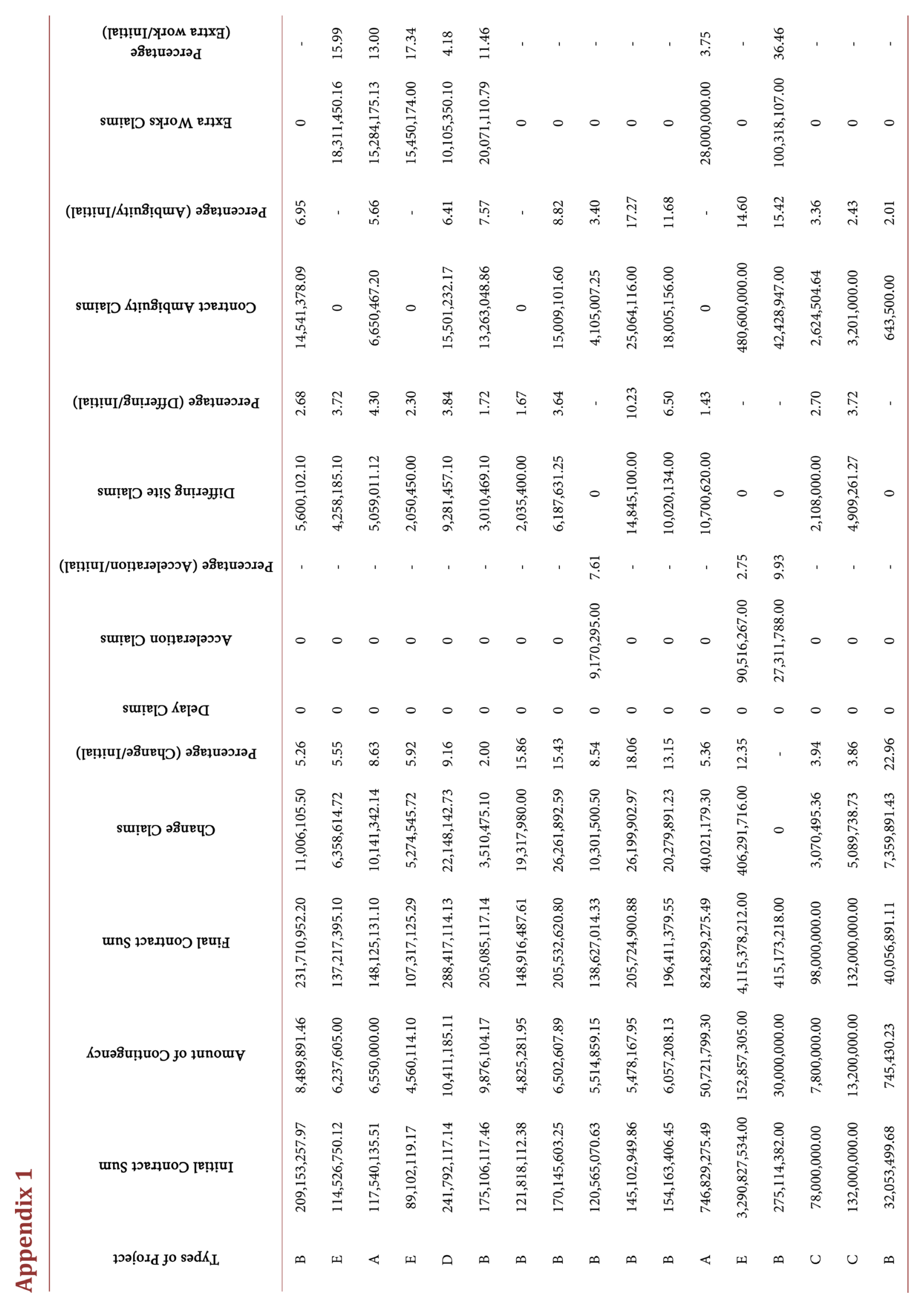




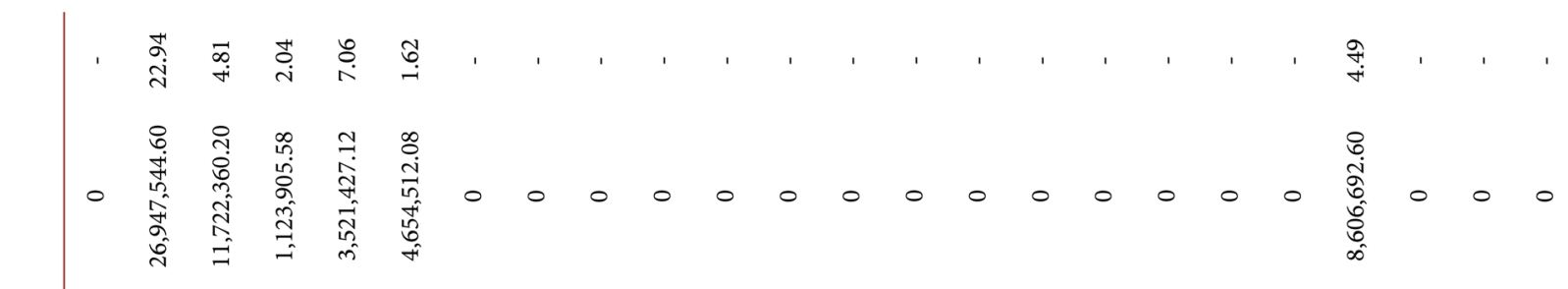

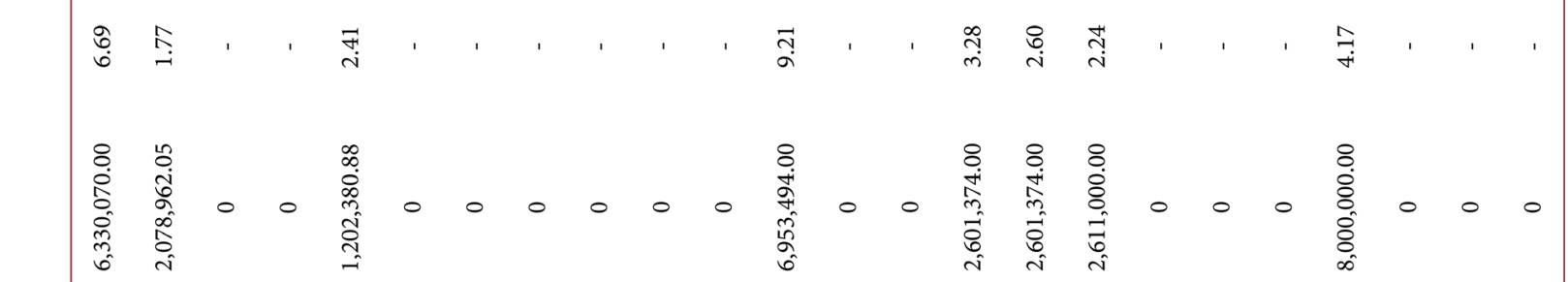

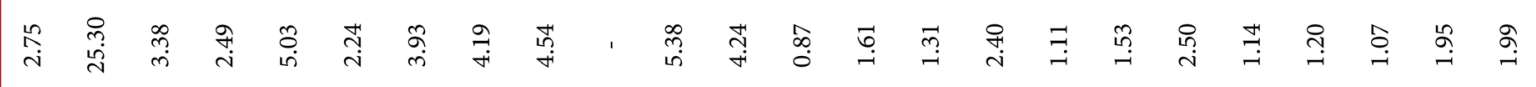

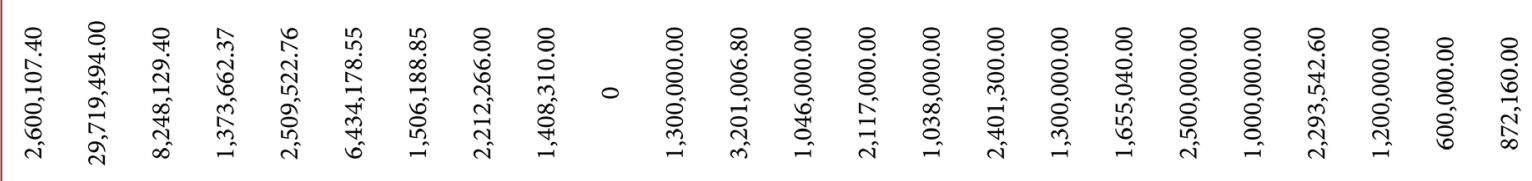

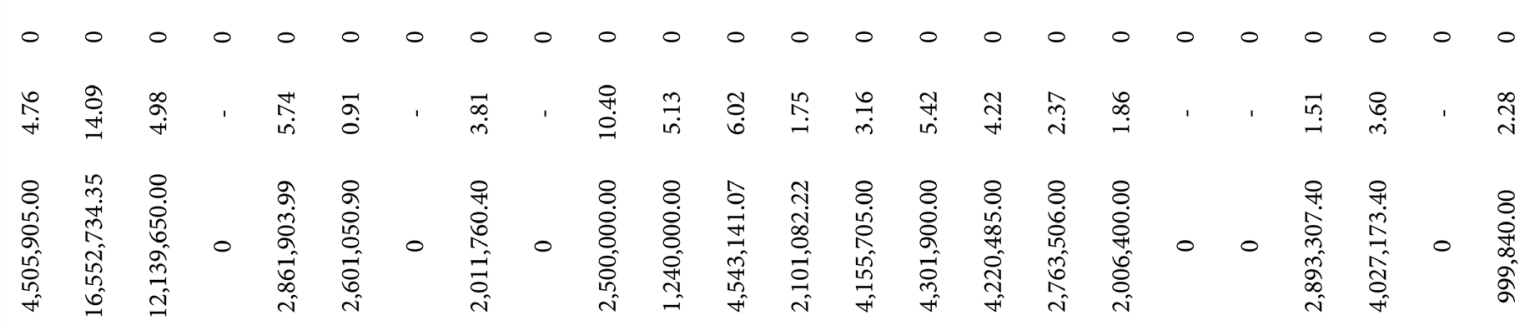

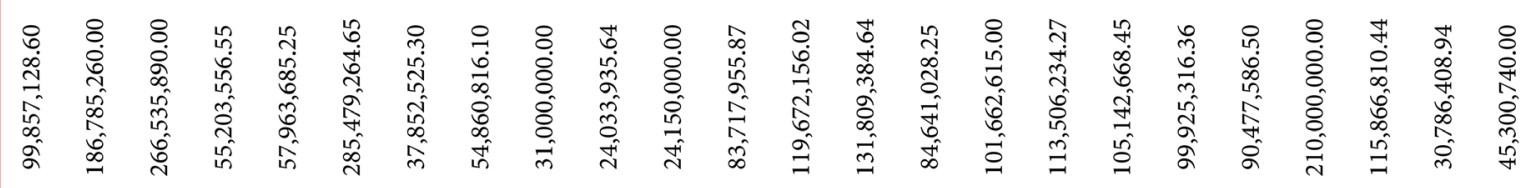

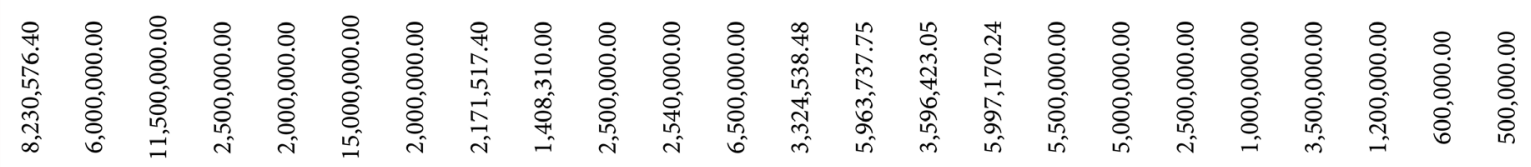

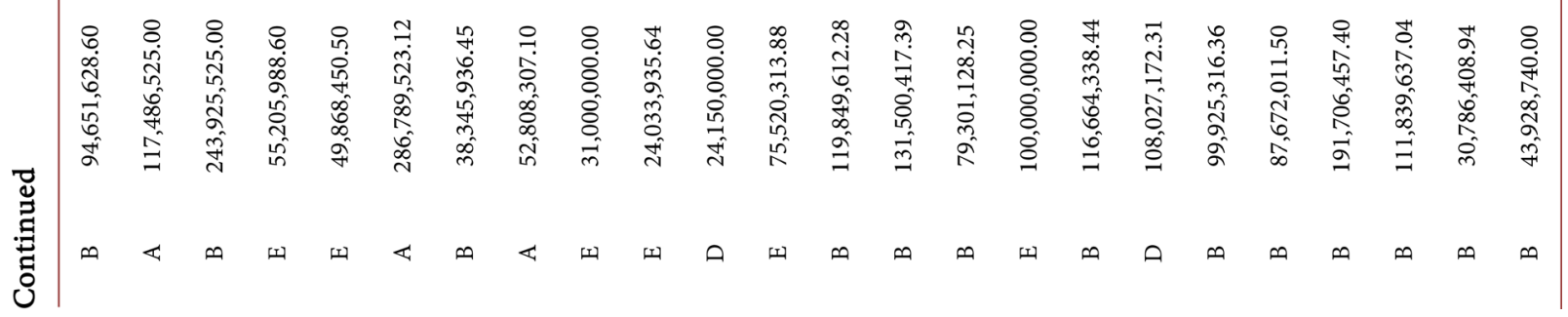




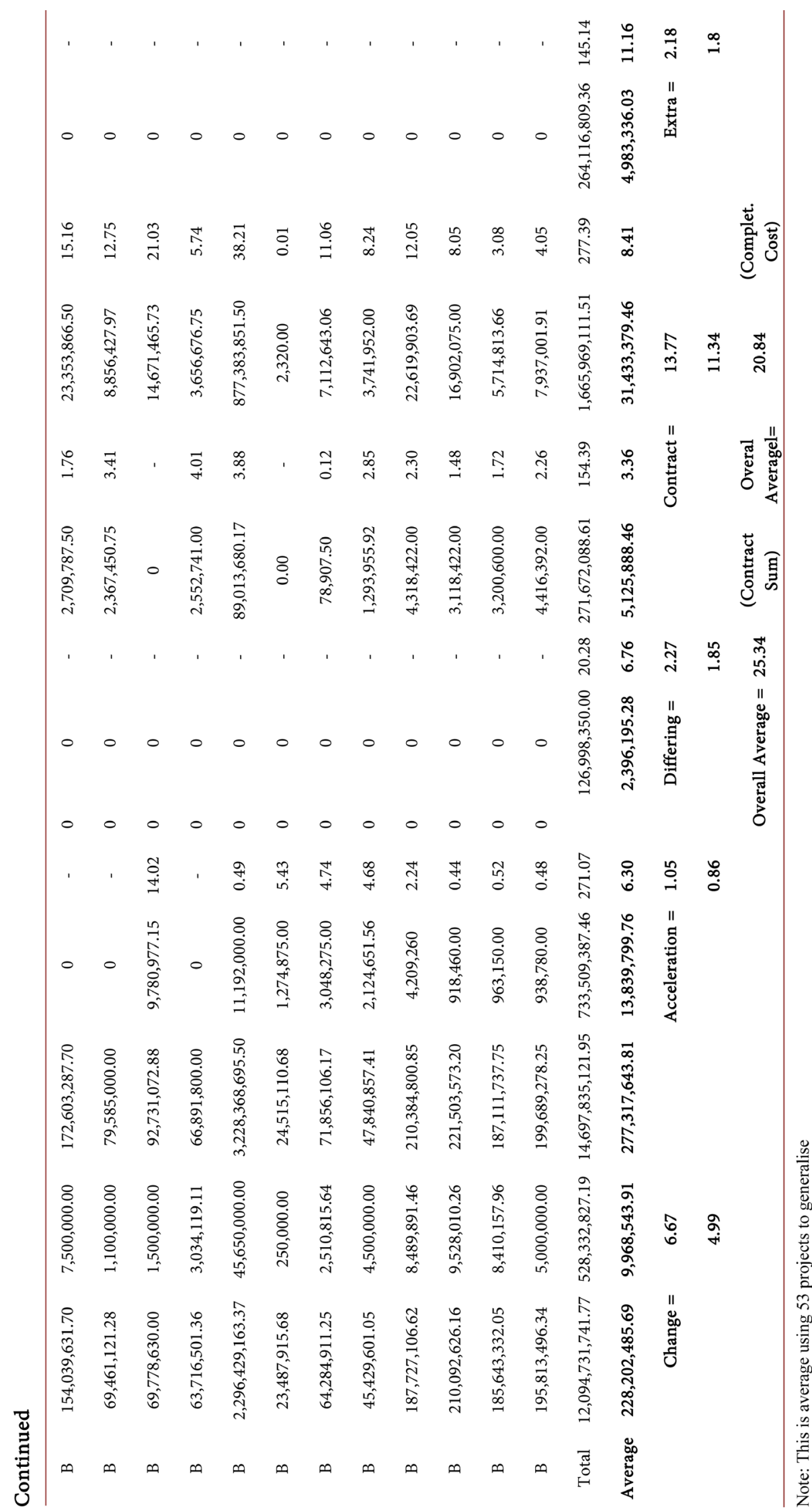


Submit or recommend next manuscript to OALib Journal and we will provide best service for you:

- Publication frequency: Monthly

- 9 subject areas of science, technology and medicine

- Fair and rigorous peer-review system

- Fast publication process

- Article promotion in various social networking sites (LinkedIn, Facebook, Twitter, etc.)

- Maximum dissemination of your research work

Submit Your Paper Online: Click Here to Submit

Or Contact service@oalib.com 